\title{
DNA Strand Scission by D-Glucosamine and Its Phosphates in Plasmid pBR322
}

\author{
Kenji Watanabe, Nobuhiro Kashige, Yukihiko Nakashima, \\ Mikie HAYASHIDA and Kunihiro Sumoto \\ Faculty of Pharmaceutical Sciences, Fukuoka University, \\ Nanakuma, Jonan-ku, Fukuoka 814-01, Japan
}

Received October 30, 1985

\begin{abstract}
DNA strand scission due to aminosugars and their derivatives in plasmid pBR322 was investigated through agarose gel electrophoresis. D-Glucosamine and its related aminosugars primarily caused single-strand scission of ccc-DNA to form oc-DNA in a time- and temperaturedependent manner. The degree of reaction was also related to the concentration of aminosugars. DGlucosamine-6-phosphate was the most active among the compounds tested, and converted ocDNA into linear-DNA and further fragmented DNA. The reaction was stimulated by $\mathrm{Cu}^{2+}$ and inhibited by catalase, superoxide dismutase, and some radical scavengers. The DNA strandscissoring activities of aminosugars were related to their nitroblue tetrazolium-reducing activities. These results support a hypothetic mechanism in which some free radicals, generated during autoxidation of aminosugars in aqueous solution, are involved in DNA strand scission.
\end{abstract}

We had found that D-glucosamine inactivated in vitro the PL-1 phage of Lactobacillus casei withuout affecting the growth of host cells by attacking the genome DNA in the virion. ${ }^{1,2)}$ Furthermore, in a preliminary test using covalently closed circular DNA of plasmid pBR322, D-glucosamine was shown to cause single-strand scission of the DNA. This mechanism was essentially similar to those proposed for L-ascorbic acid and triose reductone, ${ }^{3,7)}$ sugar phosphates, ${ }^{8 \sim 11)}$ autoxidizable synthetic polysaccharides, ${ }^{12)}$ some antitumor antibiotics, ${ }^{13 \sim 19)}$ and xanthine oxidase. ${ }^{20)}$ Since the characteristics of both D-glucosamine and plasmid pBR322 are well understood, we were interested to see if the mechanism of DNA strand scission of the $\mathrm{pBR} 322$-aminosugar system was different from that of the other systems.

In this study, therefore, we investigated in greater detail the influence of some factors on the interaction of D-glucosamine and its derivatives with ccc-DNA of plasmid pBR322 using agarose gel electrophoresis.

\section{MATERIALS AND METHODS}

Preparation of plasmid $p B R 322$ ccc-DNA. Covalently closed circular duplex DNA (ccc-DNA) of plasmid pBR322 was isolated from Escherichia coli W3350/pBR322 as described in principle by Kupersztoch-Portnoy et al ${ }^{21)}$ Each batch of pBR322 DNA was analyzed for integrity and purity by agarose gel electrophoresis, and only the DNA samples that contained more than $85 \%$ ccc-DNA were employed in analyses. Linear-DNA was prepared by treatment of cccDNA with EcoRI.

Chemicals and enzymes. D-Isoglucosamine (1-amino1-deoxy-D-fructose) acetate was synthesized from 1-deoxy1-p-toluidino-D-fructose by the method of Kuhn and Haas. ${ }^{22)}$ This compound had a mp of $136 \sim 137^{\circ} \mathrm{C}$ (dec.) [from $\mathrm{H}_{2} \mathrm{O}$-ethanol $(1: 10)$ ] [in reference, ${ }^{23)} \mathrm{mp} 137^{\circ} \mathrm{C}$ (dec.)]. Anal. Calcd. for $\mathrm{C}_{8} \mathrm{H}_{17} \mathrm{NO}_{7}: \mathrm{C}=40.16, \mathrm{H}=7.16$, $\mathrm{N}=5.86$. Found: $\mathrm{C}=40.06, \mathrm{H}=7.28, \mathrm{~N}=5.69$. D-Glucosamine-6-phosphate, D-glucosamine-1-phosphate, nitroblue tetrazolium hydrochloride, bovine blood type I superoxide dismutase ( 3,100 units $/ \mathrm{mg}$ protein), and bovine liver catalase $(3,765$ units/mg protein) were purchased from Sigma Chemical Co. Eco RI was obtained from Takara Shuzo Co. The other reagents used were of the highest grade available from Wako Junyaku Co. and Nakarai Kagaku Co. 
reaction mixture $(100 \mu \mathrm{l})$ containing $1 \mu \mathrm{g}$ of plasmid pBR322, $0.1 \mathrm{M}$ aminosugar, and $50 \mathrm{~mm}$ Tris- $\mathrm{HCl}$ buffer $(\mathrm{pH}$ 7.2), was incubated at $37^{\circ} \mathrm{C}$ unless otherwise noted. At intervals, $10 \mu \mathrm{l}$ of the reaction mixture was mixed, to end the reaction, with $3 \mu \mathrm{l}$ of $22.5 \mathrm{mMEDTA}$ ( $\mathrm{pH}$ 8.2) containing $1.5 \% \quad(\mathrm{w} / \mathrm{v}) \quad \mathrm{SDS}, \quad 25 \% \quad(\mathrm{w} / \mathrm{v})$ sucrose, and $0.02 \%$ $(\mathrm{w} / \mathrm{v})$ bromophenol blue, and the resultant mixture was analyzed directly by agarose gel electrophoresis.

Agarose gel electrophoresis. The sample containing $0.1 \mu \mathrm{g}$ DNA was layered on $0.8 \%$ agarose gels in a horizontal slab gel apparatus. Electrophoresis was done in a $40 \mathrm{~mm}$ Tris-acetate buffer (pH 8.2) containing $5 \mathrm{~mm}$ sodium acetate and $1 \mathrm{mM}$ EDTA at $100 \mathrm{~V}$ per gel for $30 \mathrm{~min}$ at room temperature. After electrophoresis, the gels were stained with ethidium bromide $(0.5 \mu \mathrm{g} / \mathrm{ml})$ for $30 \mathrm{~min}$, and washed with running water for $30 \mathrm{sec}$. Under these conditions the order of anodal migration for the three topological forms of the DNA was ccc-DNA, full-length linear duplex DNA (linear-DNA), and nicked open circular duplex DNA (oc-DNA). The ccc-DNA produced oc-DNA after single-strand scission and linear-DNA after double-strand scission. They were all detected as clearly separated bands in agarose gels. The stained DNA bands were made visible using an ultraviolet lamp $(302 \mathrm{~nm})$ and photographed with Polaroid film through a red filter. For quantitative analysis of DNA on the gels, the photographic negatives were scanned with a Shimadzu CS-920 TLC-scanner for the OD measurement, and the integral area under the DNA bands was recorded. The area under ccc-DNA was multiplied by a factor of 1.42 to correct for its reduced binding of ethidium bromide as indicated by Lloyd $e t$ al. ${ }^{14)}$

Calculation of the percentage of inhibition of DNA strand scission. When the effects of inhibitors were studied, pBR322 plasmid was added to initiate the reaction, after a 5-min preincubation of the inhibitor with aminosugar at $37^{\circ} \mathrm{C}$. The percentage of inhibition of the DNA strand scission was calculated as follows: Inhibition $(\%)=\left[(I-C) /\left(C_{0}-C\right)\right] \times 100$, where $I$ is the amount of remaining ccc-DNA of the system with inhibitor, $C$ that of a control system without inhibitor, and $C_{0}$ that of another control system without either inhibitor or aminosugar.

\section{RESULTS}

\section{Action of aminosugars on plasmid ccc-DNA}

Plasmid pBR322 of the ccc-DNA form was incubated with various aminosugars and at times the resulting DNA was analyzed by agarose gel electrophoresis. When the plasmid reacted with $D$-glucosamine, the amount of cccDNA decreased linearly with time, and the equivalent amount of oc-DNA appeared.
However, no linear-DNA was detected even after $6 \mathrm{hr}$ of incubation. This result indicates that D-glucosamine primarily caused a single-strand scission, but no double-strand scission in ccc-DNA.

D-Isoglucosamine, D-galactosamine, and Dmannosamine caused the DNA strand scission in the same way, but to a greater degree. This result is essentially consistent with findings by Nanjou et al. ${ }^{24,25)}$ using double-stranded replicative form I DNA of $\phi X 174$ phage living in Escherichia coli. On the other hand, N-acetylderivatives of these hexosamines, D-glucosaminic acid, D-glucose, 2-deoxy-D-glucose, Dglucose-1-phosphate, D-glucose-6-phosphate, and ethanolamine were not effective.

D-Glucosamine-6-phosphate scissored the most DNA strands among the aminosugars tested. As Fig. 1 shows, the oc-DNA formed from ccc-DNA by D-glucosamine-6-phosphate treatment was broken down into linear-DNA and further fragmented DNA. The DNA strand-scissoring activity of D-glucosamine-1phosphate was higher than that of D-glucosamine, but lower than that of D-glucosamine6-phosphate. These results indicate that both the C-2 amino group and C-1 aldehyde group of the molecules are indispensable for DNA strand-scissoring activity of aminosugars and that the introduction of a C-6 phosphate group promotes the reaction.

\section{Factors affecting DNA strand scission by aminosugars}

Several properties of the DNA strandscissoring action of aminosugars were investigated with both D-glucosamine and D-glucosamine-6-phosphate by testing the factors affecting the reactions.

(1) Concentration of aminosugar. The degree of the conversion of ccc-DNA to oc-DNA was related to the concentration of aminosugars. As Fig. 2 shows, in the case of D-glucosamine6-phosphate, ccc-DNA disappeared completely at a concentration of about $0.05 \mathrm{M}$. Above that concentration, the oc-DNA formed was converted to linear-DNA in a concentration-dependent manner. In the case 

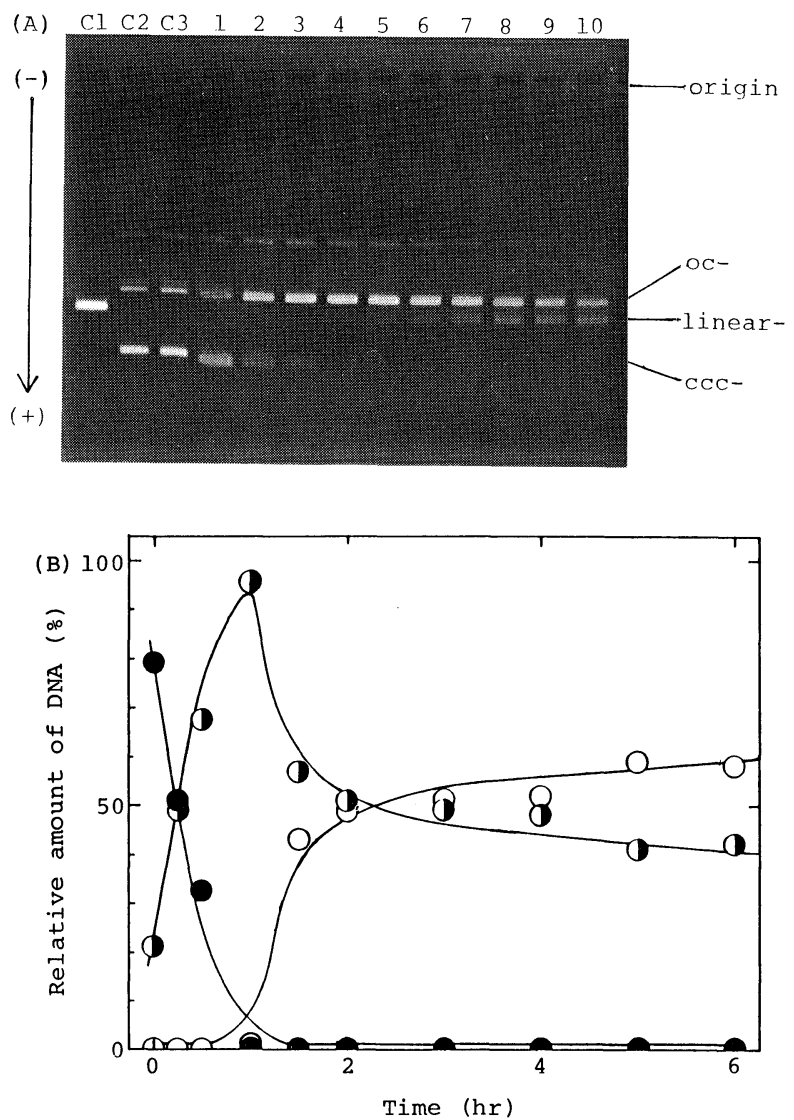

FIG. 1. Course of the Reaction of D-Glucosamine-6-phosphate with pBR-322 ccc-DNA.

Plasmid pBR322 ccc-DNA was incubated with 0.05 M D-glucosamine-6-phosphate in $50 \mathrm{~mm}$ Tris- $\mathrm{HCl}$ buffer (pH 7.2) at $37^{\circ} \mathrm{C}$, and at various times samples of the reaction products, oc-DNA and linear-DNA, were separated from ccc-DNA by agarose gel electrophoresis.

(A) Photographic negative of agarose gel after electrophoresis. The incubation times increase from left to right (lane No. $1 \sim 10$ corresponding to $0,0.25,0.5,1,1.5,2,3,4,5$, and $6 \mathrm{hr}$, respectively. $\mathrm{Cl}$, linear-DNA; C2 and C3, drug-free control at 0 and $6 \mathrm{hr}$.

(B) Graphical illustration. Relative amount of each DNA is plotted as a function of reaction time.

Symbols: $\bigcirc$, ccc-DNA; $\bigcirc$, oc-DNA; $\bigcirc$, linear-DNA.

of D-glucosamine, the degree of reaction reached the highest level around $0.2 \mathrm{M}$, above which the activity was essentially the same up to the $0.4 \mathrm{M}$ examined. This might be due to the likely activity of D-glucosamine of scavenging radicals at higher concentrations.

(2) Temperature. The rate of ccc-DNA strand scission by aminosugars depended on the incubation temperature, and was suppressed at lower temperatures. From an Arrhenius plot, the activation energy of the DNA strand scission by D-glucosamine was calculated to be about $11.9 \mathrm{kcal}$, and that by $\mathrm{D}$ - glucosamine-6-phosphate was $17.4 \mathrm{kcal}$.

(3) $p H$. The DNA strand scission by D-glucosamine was affected by the incubation $\mathrm{pH}$, and the lowest one was around $\mathrm{pH} 5.0$ with a gradual increase above that level and a sharper increase below it. On the other hand, the reaction by $D$-glucosamine-6-phosphate was almost independent of the incubation $\mathrm{pHs}$ tested.

(4) Metal ions and chelators. The effects of various metal ions on the ccc-DNA strand scission by D-glucosamine was examined using their chlorides. As Fig. 3 shows, in the pres- 


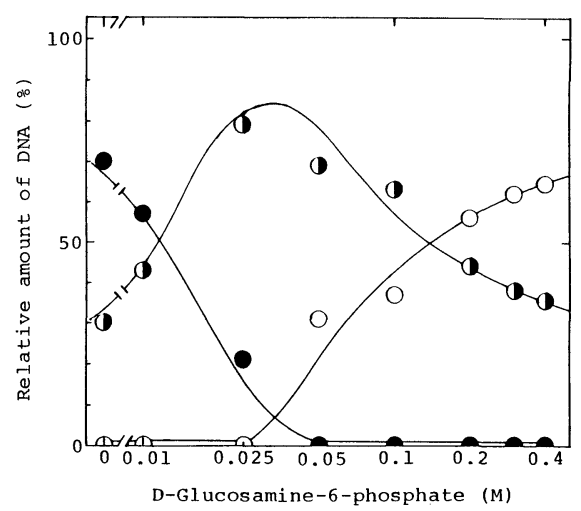

FIG. 2. Effects of the Sugar Concentration on ccc-DNA Strand Scission by D-Glucosamine-6-phosphate.

Plasmid pBR322 ccc-DNA was incubated with various concentrations of D-glucosamine-6-phosphate at $37^{\circ} \mathrm{C}$ for $3 \mathrm{hr}$ in $50 \mathrm{~mm}$ Tris- $\mathrm{HCl}$ buffer (pH 7.2). Symbols: DNA; 1 , oc-DNA; $\bigcirc$, linear-DNA.

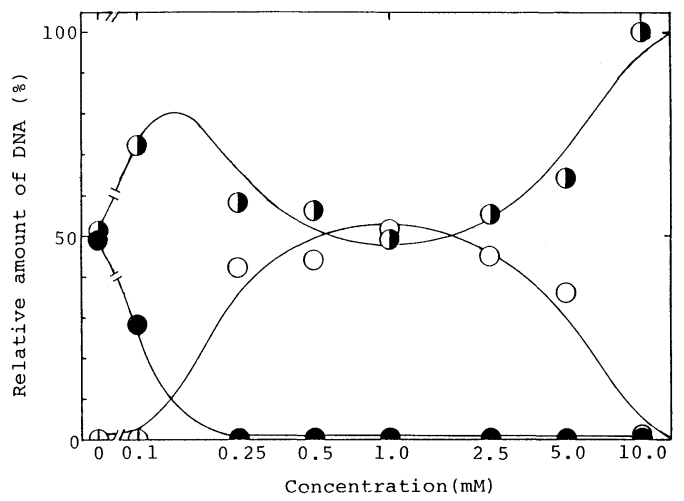

FIG. 3. Effects of the Concentration of $\mathrm{Cu}^{2+}$ on cccDNA Strand Scission by D-Glucosamine.

Plasmid pBR322 ccc-DNA was incubated with $0.1 \mathrm{M} \mathrm{D}$ glucosamine at $37^{\circ} \mathrm{C}$ for $3 \mathrm{hr}$ in $50 \mathrm{~mm}$ Tris- $\mathrm{HCl}$ buffer ( $\mathrm{pH}$ 7.2). Cupric chloride (final concentrations shown in the figure) were preincubated with $\mathrm{D}$-glucosamine at $37^{\circ} \mathrm{C}$ for $5 \mathrm{~min}$ before the DNA addition. Symbols: $\mathbf{O}$, cccDNA; $\bigcirc$, oc-DNA; $\bigcirc$, linear-DNA.

ence of $\mathrm{Cu}^{2+}$ the DNA strand scission by Dglucosamine was stimulated, with all the cccDNA being converted to oc-DNA, followed by conversion to linear-DNA and, after a prolonged reaction, still futher converted to fragmented DNA. The DNA strand scissionstimulating activity of $\mathrm{Cu}^{2+}$ was dependent on concentrations up to $1 \mathrm{~mm}$. However, in the presence of higher concentrations of $\mathrm{Cu}^{2+}$, the activity tended to decrease. The reason for an optimum concentration for $\mathrm{Cu}^{2+}$ remains unclear. On the other hand, $\mathrm{Na}^{+}, \mathrm{K}^{+}, \mathrm{Cs}^{+}$, $\mathrm{Mg}^{2}, \mathrm{Ca}^{2+}, \mathrm{Ba}^{2+}, \mathrm{Mn}^{2+}, \mathrm{Zn}^{2+}, \mathrm{Sn}^{2+}, \mathrm{Pb}^{2+}$, $\mathrm{Ni}^{2+}$, and $\mathrm{Co}^{2+}$ at $1 \mathrm{mM}$, and $\mathrm{Al}^{3+}$ and $\mathrm{Bi}^{3+}$ at $0.1 \mathrm{~mm}$ did not affect the reaction.

Diethylenetriamine-pentaacetic acid inhibited the DNA strand scission by D-glucosamine by about $50 \%$ at $10 \mu \mathrm{M}$, but the other bivalent metal ion-chelators such as EDTA and sodium citrate at the same concentration scarcely affected the reaction.

$\mathrm{Cu}^{2+}$ catalyzes the autoxidation of some reducing compounds to generate oxygen radicals and free radical derivatives in aqueous solutions containing oxygen. Thus, these radicals might be involved in the D-glucosamine-induced DNA strand scission.

(5) Enzymes and radical scavengers. Since, upon oxidation, D-glucosamine seemed to generate oxygen radicals in aqueous solution, several known enzymes and free radical scavengers were tested for inhibition of the Dglúcosamine-induced DNA strand scission. As Fig. 4 shows, the reaction was $50 \%$ inhibited in the presence of about $3 \mu \mathrm{g}$ catalase $/ \mathrm{ml}$, so $\mathrm{H}_{2} \mathrm{O}_{2}$ may be involved in the reaction. On the other hand, superoxide dismutase (SOD), which causes disproportionation in the superoxide anion radical $\left(\mathrm{O}_{2}^{-}\right)$to give $\mathrm{H}_{2} \mathrm{O}_{2}$, was a much weaker inhibitor than catalase of DNA strand scission. Simultaneous use of catalase and SOD did not increase the original ability of catalase. Among the radical scavengers tested, the reaction was inhibited most effectively by 4,5-dihydroxy-1,3-benzenedisulfonic acid (Tiron) ( ID $_{50}=0.5 \mathrm{~mm}$ ) which scavenges $\mathrm{O}_{2}^{-}$. These results show that $\mathrm{O}_{2}^{-}$is also essential for the DNA strand scission. $\mathrm{O}_{2}^{-}$is known to react with $\mathrm{H}_{2} \mathrm{O}_{2}$ to generate the hydroxyl radical $(\mathrm{OH} \cdot)$ and a singlet oxygen $\left({ }^{1} \mathrm{O}_{2}\right)^{20,26,27)}$ in addition to undergoing disproportionation. Therefore, it is likely that both $\mathrm{O}_{2}^{-}$and $\mathrm{H}_{2} \mathrm{O}_{2}$ participate indirectly as intermediates in DNA strand scission by generating $\mathrm{OH} \cdot$ and $/$ or ${ }^{1} \mathrm{O}_{2}$ through the above reaction. The fact that scavengers such as 2mercaptoethylamine hydrochloride (MEA), 


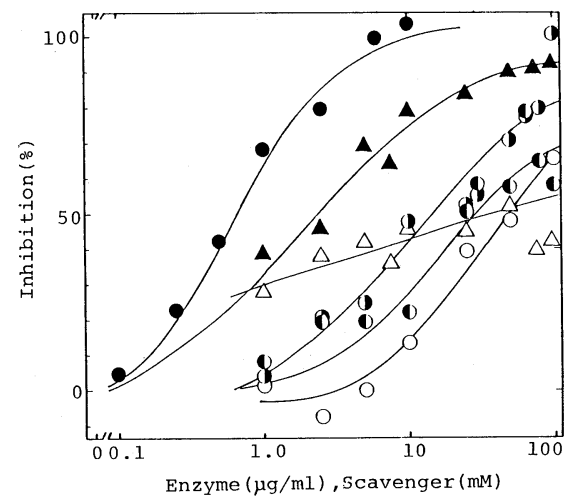

FIG. 4. Effects of Enzymes and Radical Scavengers on ccc-DNA Strand Scission by D-Glucosamine.

Plasmid pBR322 ccc-DNA was incubated with $0.1 \mathrm{M} \mathrm{D-}$ glucosamine at $37^{\circ} \mathrm{C}$ for $3 \mathrm{hr}$ in $50 \mathrm{~mm}$ Tris $-\mathrm{HCl}$ buffer (pH 7.2) in the presence of an enzyme or radical scavenger at the indicated concentrations. Symbols: $\boldsymbol{\Delta}$, catalase; $\triangle$, SOD; ๑, Tiron; 1 , MEA; $1, \mathrm{KI}, \mathrm{O}$, DMSO.

KI and dimethylsulfoxide (DMSO), also inhibited the DNA strand scission supports this assumption.

\section{Reduction of NBT by aminosugars}

As a means for correlating the DNA strandscissoring action of aminosugars with reactivity in autoxidation, the reduction of nitroblue tetrazolium chloride (NBT) by aminosugars, as monitored by measurement at $560 \mathrm{~nm}$ of diformazan formation, was investigated by the method of Beauchamp and Fridovich. $^{28)}$ The results are shown in Fig. 5 , where the rate of NBT reduction is plotted in a logarithmic scale on the ordinate and the extent of ccc-DNA strand scission on the abscissa. There was a good relationship among them except for D-glucosamine-6-phosphate which had less NBT-reducing activity than expected. Since these results show that $\mathrm{O}_{2}^{-}$is generated in the autoxidation of aminosugars and is responsible for the major part of the NBT reduction, this active oxygen was considered to be involved, directly or indirectly, in the observed damage by aminosugars to plasmid pBR322 DNA.

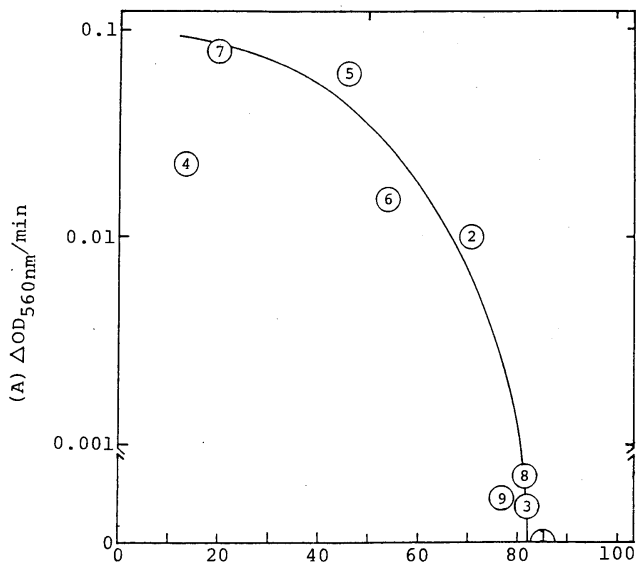

(B) Remaining ccc-DNA ( 8 )

FIG. 5. Relationship between the NBT Reducing Activity and the ccc-DNA Strand Scissoring Activity of Some Aminosugars.

(A) NBT reduction: Aminosugar $(30 \mathrm{~mm})$ was incubated with $10 \mu \mathrm{M} \mathrm{NBT}$ at $25^{\circ} \mathrm{C}$ in $30 \mathrm{~mm}$ sodium carbonate buffer (pH 10.4) containing $1 \mathrm{~mm}$ EDTA, and the OD at $560 \mathrm{~nm}$ was measured every minute to find the $\Delta \mathrm{OD}_{560} / \mathrm{min}$.

(B) ccc-DNA strand scission: Aminosugar $(30 \mathrm{~mm})$ was incubated with $0.1 \mu \mathrm{g} \mathrm{pBR} 322 \mathrm{DNA}$ at $37^{\circ} \mathrm{C}$ in $50 \mathrm{~mm}$ Tris- $\mathrm{HCl}$ buffer ( $\mathrm{pH}$ 7.2) for $3 \mathrm{hr}$, and the relative amount of remaining ccc-DNA was measured.

Symbols: (1), control without sugars; (2), GlcN; (3), GlcNAc; (4), GlcN-6-P; (5), IsoGlcN; (6), GalN; (7), ManN; (8), Glc-6-P; (9), Glc-1-P.

\section{DISCUSSION}

In this study, we have confirmed and extended previous observations ${ }^{1,2}$ on DNA strand scission by D-glucosamine. Our results using the aminosugars-pBR322 system agreed approximately with those for L-ascorbic acid, ${ }^{3 \sim 7)}$ triose reductone, ${ }^{7)}$ sugar phosphates, ${ }^{8 \sim 11)}$ autoxidizable synthetic polysaccharides, ${ }^{12)}$ and isoglucosamine, ${ }^{25)}$ all of which have characteristic properties of the reductone structure. Some of the oxygen radicals generated in the aqueous solution of aminosugars were considered to be involved in the observed damage to the plasmid DNA. It is of interest that plasmid DNA is labile enough to react with such low concentrations of oxygen radicals as were generated here. However, this is not to say that the possible incorporation of aminosugars into intact DNA never precedes 
the event that leads to strand scission. We do not know whether there are specific sites on the DNA molecule at which these strand scissions occur, or the detailed properties of the chemical reaction. $\mathrm{Cu}^{2+}$ in the aminosugarinduced DNA strand scission is presumed to be a catalyst which directly stimulates the oxidation of aminosugar or the generation of active oxygens and/or that $\mathrm{Cu}^{2+}$ is bound either to DNA or to aminosugar to give more reactive complexes.

The reactions of nucleic acids with chemical agents having characteristic properties of reductone are closely related to many important biological phenomena such as carcinogenesis, carcinostasis, mutagenesis, virus formation, virus inactivation, and aging. ${ }^{29 \sim 31}$ ) The characteristics of specific interactions of low molecular weight compounds with nucleic acids have become more clearly understood, as the base-sequences of various kinds of nucleic acids are found. Aminosugars, which have an aminoreductone structure, are widely distributed in organisms, foods, and sometimes in drugs such as antitumor antibiotics. Therefore, it is important to investigate in more detail the characteristics of the interaction between nucleic acids and aminosugars either in the absence or in the presence of $\mathrm{Cu}^{2+}$ through comparison with other nucleic acid-damaging substances such as alkylating agents and intercalating agents with a view of relating the interaction to such important bioloical phenomena.

The fact that both D-glucosamine-6-phosphate and D-isoglucosamine induced DNA strand scission more strongly than D-glucosamine itself would lead us to expect more effective agents by modification without causing critical damage to its amino-reductone structure.

Acknowledgments. We thank the following students of Fukuoka University for their technical assistance in some of the experiments: Junichi Sakanashi, Kohji Yamashita, and Masanori Kizuki.

\section{REFERENCES}

1) K. Ishibashi, T. Sasaki, S. Takesue and K. Watanabe, Agric. Biol. Chem., 46, 1961 (1982).

2) K. Watanabe, T. Sasaki, N. Kâshige, K. Ishibashi, Y. Nakashima and M. Hayashida, Agric. Biol. Chem., 49, 63 (1985).

3) A. Murata and K. Kitagawa, Agric. Biol. Chem., 37, 1145 (1973).

4) A. Murata, R. Oyadomari, T. Ohashi and K. Kitagawa, J. Nutr. Sci. Vitaminol., 21, 261 (1975).

5) K. Wong, A. R. Morgan and W. Paranchych, Can. J. Biochem., 52, 950 (1.974).

6) A. R. Morgan, R. L. Cone and T. M. Elgert, Nucl. Acids Res., 3, 1139 (1976).

7) K. Shinohara, M. So, M. Nonaka, K. Nishiyama, H. Murakami and H. Omura, J. Nutr. Sci. Vitaminol., 29, 481 (1983).

8) N. Kashimura and J. Morita, Yuhki-Gosei Kagaku, 42, 523 (1984).

9) J. Morita, N. Kashimura and T. Komano, Agric. Biol. Chem., 44, 883 (1980).

10) J. Morita and T. Komano, Agric. Biol. Chem., 47, 11 (1983).

11) J. Morita, K. Ueda, S. Nanjou and T. Komano, Nucl. Acids Res., 13, 449 (1985).

12) J. Morita, N. Kashimura and T. Komano, Agric. Biol. Chem., 44, 2971 (1980).

13) J. W. Lown and S.-K. Sin, Can. J. Biochem., 54, 446 (1976).

14) R. S. Lloyd, C. W. Haidle and D. L. Robberson, Biochemistry, 17, 1890 (1978).

15) H. Ekimoto, H. Kuramochi, K. Takahashi, A. Matsuda and H. Umezawa, J. Antibiot., 33, 426 (1980).

16) K. Ueda, J. Morita, K. Yamashita and T. Komano, Chem.-Biol. Interact., 29, 145 (1980).

17) K. Ueda, J. Morita and T. Komano, J. Antibiot., 35, 1380 (1982).

18) K. Ueda, J. Morita and T. Komano, Nucl. Acids Res. Symp. Ser., 12, 99 (1983).

19) C. K. Mirabelli, C.-H. Huang, R. G. Fenwick and S. T. Crooke, Antimicrob. Agents Chemother., 27, 460 (1985).

20) K. Brawn and I. Fridovich, Arch. Biochem. Biophys., 206, 414 (1981).

21) Y. M. Kupersztoch-Portnoy, M. A. Lovett and D. R. Helinski, Biochemistry, 13, 5484 (1974).

22) R. Kuhn and H. J. Haas, Liebigs Ann. Chem., 600, 148 (1956).

23) F. Weygand, Ber. Dtsch. Chem. Ges., 73, 1259 (1940).

24) S. Nanjou, S. Fujii, K. Tanaka, K. Ueda and T. Komano, Agric. Biol. Chem., 48, 2865 (1984).

25) S. Nanjou, S. Fujii, K. Tanaka, K. Ueda and T. Komano, Agric. Biol. Chem., 49, 459 (1985).

26) F. Haber and J. Weiss, Proc. Roy. Soc. London, Ser. A, 147, 332 (1934). 
27) I. Fridovich, "Free Radicals in Biology," Vol. I, ed. 29) H. Omura, Jpn. J. Soc. Food \& Nutr., 31, 9 (1978). by W. A. Pryor, Academic Preśs, New York, 1976, 30) H. Murakami, Nippon Nôgeikagaku Kaishi, 57, 55 pp. $239 \sim 277$. (1983).

28) C. Beauchamp and I. Fridovich, Anal. Biochem., 44, 31) R. Bucala, P. Model and A. Cerami, Proc. Natl. 276 (1971). Acad. Sci., U.S.A., 81, 105 (1984). 